Article

\author{
SILVA, J.R.O. ${ }^{1}$ \\ MARQUES, J.N.R. ${ }^{1}$ \\ GODOY, C.V.C. ${ }^{1}$ \\ BATISTA, L.B. ${ }^{1}$ \\ SILVA A.A. ${ }^{2}$ (D) \\ RONCHI, C.P. ${ }^{1 *}$
}

\section{2,4-D HORMESIS EFFECT ON SOYBEAN}

\section{Hormese de 2,4-D em Soja}

ABSTRACT - The hormesis effect of 2,4-D, applied at two stages of soybean development, on the physiological components of crop yield, was investigated. Soybean seeds of the cultivar 'AG 3680 IPRO' were sown in pots containing $7 \mathrm{~L}$ of a substrate and kept in a greenhouse. A randomized complete block design with four replicates was used. Eighteen treatments were tested, arranged in a split-plot scheme. The plots consisted of two stages of herbicide application (V4 and V6), and the split-plots were arranged by nine 2,4-D doses $\left(0,5,10,15,20,25,30,40\right.$, and $\left.50 \mathrm{~g} \mathrm{ha}^{-1}\right)$. At the time of harvest, 100 days after sowing, significant interactions between crop development stages and 2,4-D doses were observed for the number of nodes in the main stem (NNMS) and the number of pods per plant (NPP). Both NNMS and NPP were not affected by 2,4-D during V6, but they increased with doses up to $20.2 \mathrm{~g} \mathrm{ha}^{-1}$ and $22.5 \mathrm{~g} \mathrm{ha}^{-1}$, respectively, during V4 and declined at higher doses according to a quadratic model, thus characterizing hermetic effect. Regardless of the application stage, the number of grains per plant and weight of a thousand grains were reduced as doses increased. However, the grain number and grain mass per plant reached maximum values for doses of $20.3 \mathrm{~g} \mathrm{ha}^{-1}$ and $12.9 \mathrm{~g} \mathrm{ha}^{-1}$, respectively. It was concluded that 2,4-D causes hormesis effects on the soybean crop 'AG 3680 IPRO' pot-grown in greenhouse conditions, regardless of the application stages herein tested.

Keywords: Glycine max, auxin, herbicide.

RESUMO - Investigou-se o efeito hormético do 2,4-D, aplicado na soja em dois estádios de desenvolvimento, sobre os componentes fisiológicos de produtividade da cultura. Sementes de soja da variedade 'AG 3680 IPRO' foram semeadas em vasos contendo $7 \mathrm{~L}$ de substrato, mantidos em casas de vegetação. Foram avaliados 18 tratamentos no delineamento em blocos casualizados, com quatro repetições, dispostos em esquema de parcelas subdivididas. As parcelas foram constituídas por dois estádios de desenvolvimento (V4 e V6), e as subparcelas, por nove doses de 2,4-D (0, 5, 10, 15, 20, 25, 30, 40 e $\left.50 \mathrm{~g} \mathrm{ha}^{-1}\right)$. Na colheita, aos 100 dias após a semeadura, verificou-se interação significativa entre estádio e dose de 2,4-D para o número de nós na haste principal (NNHP) e para o número de vagens por planta (NDV). O NNHP e o NDV não foram afetados pelo 2,4-D em V6, mas em V4 eles

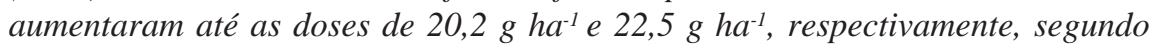
modelo quadrático, declinando em doses maiores, conferindo o efeito hormético. Independentemente do estádio de aplicação, o número de grãos por vagem e o peso de mil grãos reduziram-se com o aumento da dose. Todavia, o número de grãos e a massa de grãos por planta atingiram valores máximos para as doses de 20,3 $\mathrm{g} \mathrm{ha}^{-1}$ e 12,9 $\mathrm{g} \mathrm{ha}^{-1}$, respectivamente. Concluiu-se que o 2,4-D promove hormese na cultura da soja 'AG 3680 IPRO', cultivada em vasos em casa de vegetação,

\section{(Co} independentemente dos estádios de aplicação testados.

Palavras-chave: Glycine max, auxina, herbicida.

${ }^{1}$ Universidade Federal de Viçosa, Florestal-MG, Brasil; ${ }^{2}$ Universidade Federal de Viçosa, Viçosa-MG. Brasil.

\section{* Corresponding author:}

Received: October 31, 2018

Approved: May 23, 2019

\section{Copyright: This is an open-access article distributed under the terms of the Creative Commons Attribution License, which permits unrestricted use, distribution, and reproduction in any medium, provided that the original author and source are credited. \\ Planta Daninha 2019; v37:e019216022}
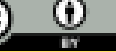


\section{INTRODUCTION}

Hormesis is the term used to designate the stimulus (beneficial effect) to the development of an organism generated by the application of small doses (or sub-doses) of molecules, which in normal doses would cause an inhibitory or lethal effect on these organisms (Calabrese and Baldwin, 2002). This term, coined in 1942, is derived from the Greek word "hormo," which means hormone, and was first used to describe the stimulus to fungal growth generated through application of a low concentration of antibiotics that in high concentrations suppressed the growth of fungi (Luckey, 1991; 2006). Regarding plants, the hormetic effect can be promoted by many substances, such as herbicides (Duke et al., 2006).

Herbicides are chemical substances capable of killing or drastically inhibiting the growth of certain plant species (Silva et al., 2007). Herbicides have been used in agriculture since the middle of the last century (Cobb and Reade, 2010) to control weeds in agricultural and nonagricultural areas, in pre- or post-emergence applications, which can be selective to certain species of plants of human interest. Although full doses are lethal or strongly inhibit the growth of sensitive plant species, when used in small doses, they may stimulate plant development, thus characterizing the hormetic effect (Duke et al., 2006). Some examples of herbicides that have shown hormetic effect are glyphosate and 2,4-D.

Glyphosate, which is an inhibitor of aromatic amino acid biosynthesis, is used for postemergence non-selective weed control, which is applied in the total pre-planting area or directed spray applications in perennial (Bridges, 2003) and transgenic (Monquero, 2005) crops. The increase in productivity of bean crops (Silva et al., 2016) and the increase of the biomass in soybean (Velini, 2008; Silva, 2014), rice (Gitti et al., 2011), and sourgrass plants (Anunciato, 2018) was observed as a result of the application of small doses of glyphosate, generally ranging from $1.75 \mathrm{~g} \mathrm{ha}^{-1}$ to $18.2 \mathrm{~g} \mathrm{ha}^{-1}$.

Contrarily, 2,4-D is an auxin mimic herbicide, which is also used in post-emergence applications for the control of non-grass weeds in grass cultures (Silva et al., 2007). The effect of hormesis in the application of sub-doses of this herbicide was evidenced, for example, by an increase in the leaf area in pequi plants (Tavares et al., 2017). Unlike glyphosate, the hormetic effect of 2,4-D appears to be more easily linked with its mechanism of action, specifically with the physiological effects of auxins on plants.

Auxins, such as the indoleacetic acid (IAA), are naturally occurring hormones in plants (Taiz et al., 2017). At concentrations of $10^{-13}$ to $10^{-8}$ and $10^{-7}$ to $10^{-4} \mathrm{M}$ in plant tissues, auxins promote the growth of roots and stems, respectively, whereas, at concentrations higher than these, they strongly inhibit the growth of these organs (Goodwin and Mercer, 1983; Taiz et al., 2017). Therefore, 2,4-D causes hormonal imbalance in cells at high doses, with consequent disordered tissue growth and hyponasty as the main symptoms of toxicity in plants (Silva et al., 2007). However, it can increase the growth of the plant in sub-doses by stimulating the cell elongation according to the Acid Growth Theory (Rayle and Cleland, 1992; Taiz et al., 2017).

In this sense, sub-doses of 2,4-D are believed to cause a hormetic effect in soybeans. Although not generalized, this herbicide has been used to stimulate the productivity of some soybean cultivars in some plantations in Brazil. Doses of $7 \mathrm{~g} \mathrm{ha}^{-1}$ to $10 \mathrm{~g}^{\text {ha }} \mathrm{g}^{-1}$ have been used in cultivars planted in smaller stands $\left(\approx 15\right.$ plants $\left.\mathrm{m}^{-1}\right)$ in order to promote greater development, whereas it has not been used for the cultivars planted in bigger stands $\left(\approx 2224\right.$ plants $\mathrm{m}^{-1} ; \mathrm{H}$.V. Rocha, personal communication). Besides promoting the cellular expansion mentioned above, this molecule also seems to stimulate a greater floral profusion in the plant, leading to a greater number of pods per plant or even altering other physiological components associated with the productivity of this crop. It is known that a higher number of pods per plant may leads to a higher number of grains per square meter, which is the main component of soybean yield (Board and Maricherla, 2008; Van Roekel et al., 2015).

Soybean is one of the most important grain for animal and human consumption in the world. Its cultivation covers around 125 million hectares, with the main producing countries being the USA and Brazil (USDA, 2018). In Brazil, 35.2 million hectares of land are used for soybean production, with a production of 120.5 million tons recorded during the $2017 / 2018$ harvest (Conab, 2018), and generation of an annual foreign exchange worth 33.7 billion USD 
(Agrostat, 2018). Considering this economic and social importance of soybean, the use of small doses of 2,4-D aimed at inducing the hormetic effect may represent increases in crop productivity. Moreover, risks of 2,4-D spray drift to sensitive soybean crop may be diminished when it is used in 2,4-D-resistent soybean.

However, it is difficult to define the doses that are supposedly associated with the hormetic effect. This is because supra-optimal doses of 2,4-D can cause severe toxicity in soybean plants, leading to significant losses in productivity. Robinson et al. (2013), for example, demonstrated that 2,4-D toxicity in soybean plants resulted in dramatically reduced seed yields. In Brazil, field reports indicate 2,4-D toxicity in crops when they were treated with this herbicide aiming to achieve the hormetic effect (H.V. Rocha, Personal Communication), suggesting that the responses depend on the cultivar used. However, the stage during the vegetative cycle in which the application needs to be made may affect the final result, since the tolerance of the soybean to 2,4-D toxicity varies with the stage of development (Slife, 1956; Wax et al.,1969; Robinson et al., 2013). In the field, the 2,4-D sub-dose applications are done during V4 stages.

Therefore, aiming to guide the doses to be used in the field, the objective of this study was to evaluate if 2,4-D promotes hormesis in soybean and if this effect is dependent on the vegetative stage during its application.

\section{MATERIAL AND METHODS}

The experiment was carried out in a greenhouse with soybean plants cultivated in plastic pots of 7 L capacity from November 2016 to March 2017. The substrate used to fill the pots consisted of soil from B horizon, sand, and cattle manure in the proportion of $3: 1: 1(\mathrm{v} / \mathrm{v} / \mathrm{v})$. The soil was classified as a dystrophic red-yellow argisol of clayey texture. Its chemical and physical characteristics are presented in Table 1. The liming and soil fertilization were performed by adding $1.0 \mathrm{~kg}$ of dolomitic limestone, $0.5 \mathrm{~kg}$ of $\mathrm{K}_{2} \mathrm{O}$ and $5.0 \mathrm{~kg}$ of $\mathrm{P}_{2} \mathrm{O}_{5} \mathrm{~m}^{-3}$ in the form of limestone, potassium chloride, and single superphosphate, according to the general recommendation for the substrate preparation (Ribeiro, 1999).

Table 1 - Physical and chemical characteristics of the soil used to prepare the substrate filling the pots

\begin{tabular}{|c|c|c|c|c|c|c|c|c|c|c|c|}
\hline \multicolumn{12}{|c|}{ Granulometric analysis (\%) } \\
\hline \multicolumn{4}{|c|}{ Thick sand } & \multicolumn{2}{|c|}{ Fine sand } & & \multicolumn{2}{|c|}{ Silt } & \multicolumn{3}{|c|}{ Clay } \\
\hline \multicolumn{3}{|c|}{24.20} & & \multicolumn{2}{|c|}{13.92} & \multicolumn{3}{|c|}{8.36} & \multicolumn{3}{|c|}{53.52} \\
\hline \multicolumn{12}{|c|}{ Chemical analysis } \\
\hline \multirow{2}{*}{$\mathrm{pH}$} & $\mathrm{P}$ & $\mathrm{K}$ & $\mathrm{Al}^{3+}$ & $\mathrm{Ca}^{2+}$ & $\mathrm{Mg}^{2+}$ & $\mathrm{H}+\mathrm{Al}$ & SB & $\mathrm{t}$ & $\mathrm{T}$ & $\mathrm{V}$ & $\mathrm{M}$ \\
\hline & \multicolumn{2}{|c|}{$\left(\mathrm{mg} \mathrm{dm}^{-3}\right)$} & \multicolumn{7}{|c|}{$\left(\mathrm{cmol}_{\mathrm{c}} \mathrm{dm}^{-3}\right)$} & \multicolumn{2}{|c|}{$(\%)$} \\
\hline 5.8 & 0.6 & 49 & 0.03 & 0.95 & 0.28 & 1.74 & 1.35 & 1.38 & 3.09 & 43.79 & 2.18 \\
\hline
\end{tabular}

Analyses carried out in the Laboratory of Agricultural Chemistry - BR 040, km 527, CEASA, Contagem, MG. The method used in the granulometric analysis does not include soils of calcareous regions and soils with organic matter content greater than $5 \%$. Granulometry Adapted pipette method. 65 mesh $(0.22 \mathrm{~mm}) . \mathrm{pH}$ in water, soil water ratio 1:2.5. $\mathrm{SB}=\mathrm{Sum}$ of bases; $\mathrm{t}=$ Effective cation exchange capacity; $\mathrm{T}=$ cation exchange capacity; $\mathrm{m}=$ saturation index of aluminum; $\mathrm{V}=$ saturation index by base. Note: The calculation of $\mathrm{SB}, \mathrm{T}, \mathrm{t}$, $\mathrm{m}$ and $\mathrm{V}$ did not consider $\mathrm{Na}$ values. Extraction solution: $\mathrm{P}$ and $\mathrm{K}-$ Mehlich; $\mathrm{Ca}, \mathrm{Mg}$ and $\mathrm{Al}-\mathrm{KCl} 1 \mathrm{~N}$. $\mathrm{H}+\mathrm{Al}-\mathrm{pH}$ in S.M.P.

Five soybean seeds of the variety AG 3680 IPRO (AGROESTE ${ }^{\circledR}$ ) of super-early cycle and indeterminate growth habit were inoculated with a liquid inoculant (Biovida Soja ${ }^{\circledR}$ ) at a dose of $60 \mathrm{~mL}$ per $50 \mathrm{~kg}$ of seeds, and then seeded in each pot and thinned 5 days after emergence, leaving two plants per pot. The plants were cultivated with periodic irrigation to maintain the soil near the field capacity. The meteorological variables, minimum, average, and maximum temperatures, as well as relative humidity (Figure 1), were collected daily from thermometers and psychrometers installed in a meteorological shelter inside the greenhouse.

The treatments were distributed in a randomized complete block design with four replicates. Eighteen treatments were used, consisting of the combination of two stages of development 


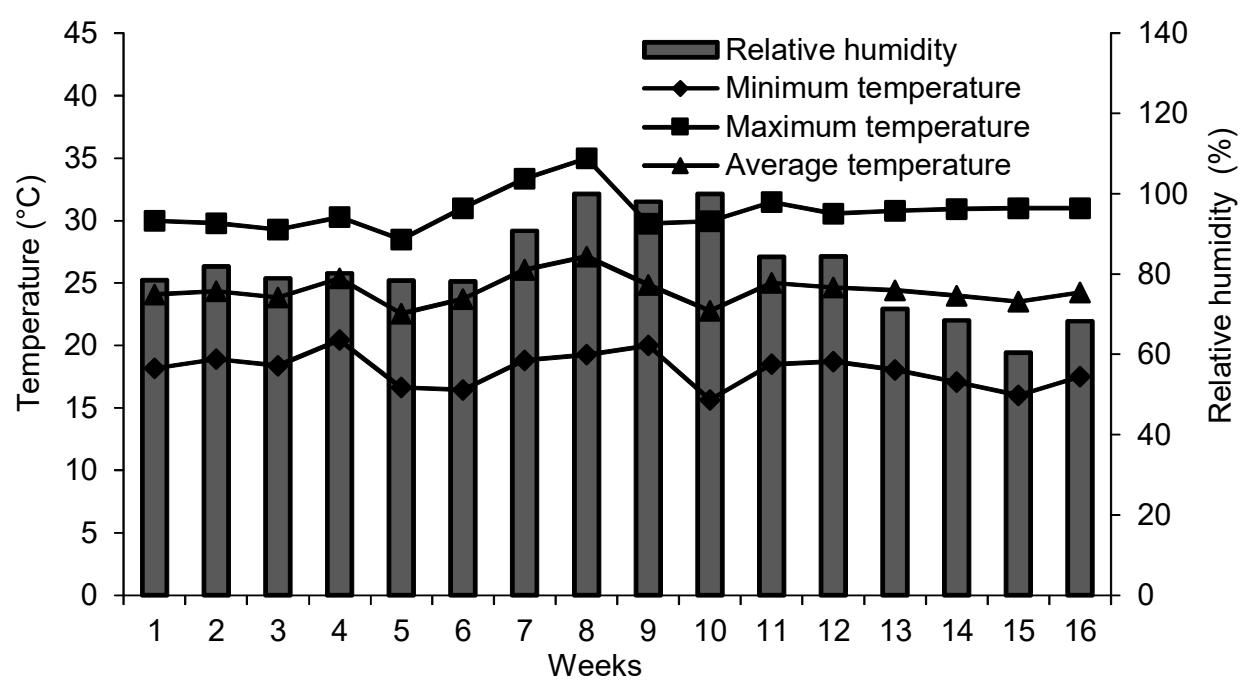

Figure 1 - Variations of the meteorological conditions (relative humidity and minimum, average, and maximum temperatures) within the greenhouse during the experimental period counted in weeks after the transplant, carried out on 11/16/2016.

(V4 and V6) and nine doses of 2,4-D (0, 5, 10, 15, 20, 25, 30, 40, and $50 \mathrm{~g}^{-1} \mathrm{~h}^{-1}$. They were arranged in a split-plot scheme, with the stages of development being allocated in the plots and the doses in the subplots. The V4 and V6 stages were chosen based on field reports from producers (H.V. Rocha, personal communication), who have used this technology mainly in V4 in order to stimulate multiple stems per soybean plant. The identification of the stages was based on the number of nodes in the main stem and in the development of the trifoliate leaf in the nodes (e.g., V4: the fourth node in the main stem presenting the third fully developed trefoil), according to Fehr and Caviness (1977). The application of the herbicide was done during V4 or V6 with a $\mathrm{CO}_{2}$ pressurized backpack sprayer of precision, with a pressure $200 \mathrm{kPa}$. The spray volume of 2,4-D herbicide was of $200 \mathrm{~L} \mathrm{ha}^{-1}$, with the spray rod containing two 100.03 flat fan spray nozzles spaced $0.5 \mathrm{~m}$ apart.

Two applications were made for phytosanitary management, the first of Priori Top ${ }^{\circledR}\left(200 \mathrm{~g} \mathrm{~L}^{-1}\right.$ azoxystrobin $+125 \mathrm{~g} \mathrm{~L}^{-1}$ difenoconazole) at a dose of $0.3 \mathrm{~L} \mathrm{ha}^{-1}$ to control powdery mildew (Erysiphe diffusa) during V5, and the second application of $\mathrm{Kraft}^{\circledR}\left(36.0 \mathrm{~g} \mathrm{~L}^{-1}\right.$ abamectin) at the dose of $0.1 \mathrm{~L} \mathrm{ha}^{-1}$ to control red spider mites (Tetranychus urticae) during V7. In both applications, the adjuvant Nimbus ${ }^{\circledR}\left(428 \mathrm{~g} \mathrm{~L}^{-1}\right.$; mineral oil) was used at a dose of $0.5 \mathrm{~L} / 100 \mathrm{~L}$ of spray.

At the end of the crop cycle, 100 days after sowing, the plants were harvested and the number of nodes in the main stem (NNMS), as well as the physiological components of the yield: number of pods per plant (NPP), number of grains per pod (GPP), number of grains per plant (GPL), weight of a thousand grains (WTG), and grain mass per plant (GMP) were evaluated standardizing the moisture content in $13 \%$.

The assumption checking of the analysis of variance was done by the graphical analysis of the residues (Neter et al., 1990), along with the maximum F-Test for the homogeneity of the variances. With no transformations required, the data were submitted to the analysis of variance and regression analysis. The regression models were adjusted by relating the variables with the 2,4-D doses, choosing models with high $\mathrm{R}^{2}$, the significance of the parameters of the equation by the $t$-test, and biological logic. The Pearson correlations $(\mathrm{p}<0.01)$ were made with the physiological components of the crop productivity.

\section{RESULTS AND DISCUSSION}

A few days after the application of the 2,4-D herbicide, either during V4 or V6, visual symptoms of toxicity were observed in the shoot of the soybean plants in treatments with doses equal to or greater than $20 \mathrm{~g} \mathrm{ha}^{-1}$ (Figure 2). At this dose, the symptoms were mild and were characterized by a discrete bending of the main stem relative to its vertical axis. However, strong toxicity symptoms were observed at doses equal to or greater than $30 \mathrm{~g} \mathrm{ha}^{-1}$, which were characterized 


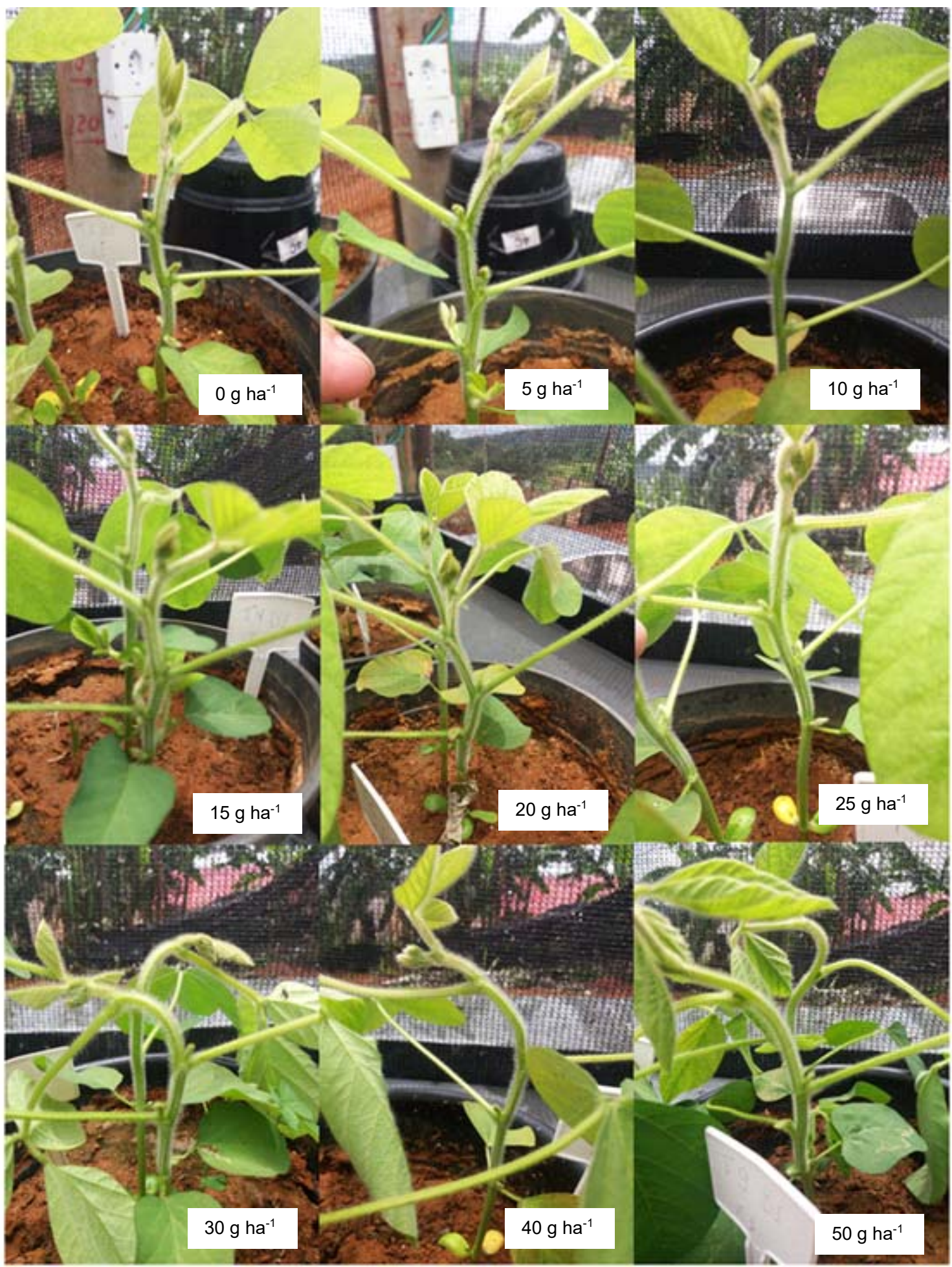

Figure 2 - Effect of sub-doses of 2,4-D on the soybean cultivation at V4 stage. Symptoms such as stem bending and hyponasty of the leaves appeared upon application of the dose $20 \mathrm{~g} \mathrm{ha}^{-1}$, becoming evident at the dose $30 \mathrm{~g} \mathrm{ha}^{-1}$.

by acute stem bending, leaf hyponasty, and reduced growth, as described in detail by Robinson et al. (2013) for the soybean crop. These toxicity symptoms are typical of sensitive dicotyledonous plants treated with auxin herbicides, since they cause a hormonal imbalance affecting protein synthesis, osmotic regulation, and cell wall plasticity when they bind to proteins in the cell membranes (Cobb and Reade, 2010). It is worth emphasizing that Robinson et al. (2013) showed that soybean yield was only affected when the toxicity reached a minimum of $20 \%$, which coincided with the application of doses equal to or greater than $29 \mathrm{~g} \mathrm{ha}^{-1}$ during V5. 
There was a interaction between the stage of development and the dose of 2,4-D for the variables NNMS and NPP (Table 2). In the case of NNMS, it was unaffected by the doses of 2,4-D when applied during V6 but responded positively to the increase of the dose of 2,4-D during V4 up to the maximum dose of $20.2 \mathrm{~g} \mathrm{ha}^{-1}$, declining after that (Figure 3A). Although it is not a direct physiological component of the soybean yield, NNMS is an important variable because it is related to the growth and productivity of the plant, considering that a trifoliate leaf is developed in each node, in which axil a lateral bud can change into a branch or inflorescence (Müller, 1981).

Similarly, the NPP was not affected by the doses of 2,4-D applied during V6, but with the early application (during V4), the NPP increased with the increase of the dose of the herbicide, reaching a maximum value equal to 82 pods/plant at the dose of $20.16 \mathrm{~g} \mathrm{ha}^{-1}$ (an increase of $27.6 \%$ in relation to the control treatment) and declining from that point (Figure 3B). This stimulus for greater production of pods per plant, which is one of the main components of the soybean yield (Müller, 1981; Navarro Júnior and Costa, 2002; Board and Maricherla, 2008; Heiffig et al., 2010), seems to represent a hormetic effect of 2,4-D. However, at the highest tested dose $\left(50 \mathrm{~g} \mathrm{ha}^{-1}\right)$, there was a reduction of $12.16 \%$ in the NPP in relation to the control treatment.

The results above corroborate the field observations, which point to a greater development and, consequently, higher pod yield per plant when they are exposed to sub-doses of 2,4-D. Because this herbicide is a synthetic auxin, it mimics the growth hormone auxin when it is applied in small doses and stimulates plant growth (Allender, 1997). In this sense, considering that the number of pods per plant is determined by the growth rate of the crop during the emergence until R5 (Board et al., 1992; Fageria et al., 2006), the application of sub-doses of 2,4-D during early vegetative stages may potentiate this component of the soybean yield.

The GPP number, regardless of the stages of application, was linearly reduced with the increase of the dose of 2,4-D (Table 2; Figure 3C), indicating that it is a physiological component of the soybean productivity that is sensitive to herbicide-induced toxicity. However, this reduction was barely significant, reaching only $4 \%$ and $11 \%$ at the doses of $20 \mathrm{~g} \mathrm{ha}^{-1}$ and $50 \mathrm{~g} \mathrm{ha}^{-1}$, respectively, in relation to the control treatment (Figure 3C). This result is consistent with the literature, in which GPP is considered a physiological component of the soybean yield that is weakly affected by production and/or environmental factors and shows strong genetic control (Heiffig et al., 2010; Costa, 2013). It should be noted that the inverse correlation between GPP and NPP, although significant, was very low $(\mathrm{r}=-0.42)$, indicating that the discrete reduction in GPP was caused by other factors besides the increase in NPP. However, even with this reduction, GPL responded positively to the increase of the dose of 2,4-D (Table 2, Figure 3D), reaching a maximum value of 178.4 grains per plant at the dose of $20.3 \mathrm{~g} \mathrm{ha}^{-1}$, regardless of the stage at which the herbicide was applied. This response was certainly a reflection of the positive effects of 2,4-D on NPP (with the correlation coefficient between NPP and GPL being of $0.80, \mathrm{p}<0.01$ ) and apparently characterizes the hormetic effect, as defined by Luckey $(1991 ; 2006)$.

Table 2 - Effect of sub-doses of 2,4-D applied at two stages of development (V4 and V6) on number of nodes in the main stem (NNMS), number of pods per plant (NPP), number of grains per pod (GPP), number of grains per plant (GPL), weight of a thousand grains (WTG), and grain mass per plant (GMP) of soybean.

\begin{tabular}{|l|c|c|c|c|c|c|c|}
\hline \multirow{2}{*}{ Source of variation } & \multirow{2}{*}{ DF } & \multicolumn{6}{|c|}{ Mean square } \\
\cline { 3 - 8 } & & NNMS & NPP & GPP & GPL & WTG & GMP \\
\hline Blocks & 3 & $3.6896^{*}$ & $7.0930^{\text {ns }}$ & $0.0109^{\text {ns }}$ & $2.3839^{\text {ns }}$ & $342.8745^{*}$ & $9.1664^{\text {ns }}$ \\
\hline Stage $(A)$ & 1 & $2.3472^{\text {ns }}$ & $8.3800^{\text {ns }}$ & $0.0192^{\text {ns }}$ & $136.7368^{\text {ns }}$ & $227.623^{* *}$ & $101.5920^{* *}$ \\
\hline Error $(a)$ & 3 & $0.1453^{\text {ns }}$ & $19.2926^{\text {ns }}$ & $0.0006^{\text {ns }}$ & $98.1624^{\text {ns }}$ & $116.2044^{\text {ns }}$ & $8.1586^{\text {ns }}$ \\
\hline Dose $(B)$ & 8 & $3.3418^{*}$ & $230.6387^{* *}$ & $0.1107^{* *}$ & $839.0527^{* *}$ & $440.0720^{* *}$ & $34.1754^{* *}$ \\
\hline$A B$ & 8 & $4.0868^{* *}$ & $79.1248^{* *}$ & $0.0346^{\mathrm{ns}}$ & $98.7119^{\text {ns }}$ & $136.1033^{\text {ns }}$ & $7.3218^{\text {ns }}$ \\
\hline Error $(b)$ & 48 & 1.2213 & 38.10307 & 0.0165 & 245.1865 & 92.7606 & 6.6773 \\
\hline CV $(\%)-$ subparcel & & 7.32 & 8.42 & 5.51 & 9.20 & 5.98 & 5.51 \\
\hline CV $(\%)-$ parcel & & 2.53 & 5.99 & 1.06 & 5.82 & 6.70 & 9.44 \\
\hline Overall average & & 15.09 & 73.27 & 2.33 & 170.27 & 160.95 & 27.39 \\
\hline
\end{tabular}

DF: degrees of freedom; CV: coefficient of variation; ** and *: significant at $1 \%$ and $5 \%$ of probability, respectively, by the F-test; ns: not significant at $5 \%$ of probability by the F-test. 

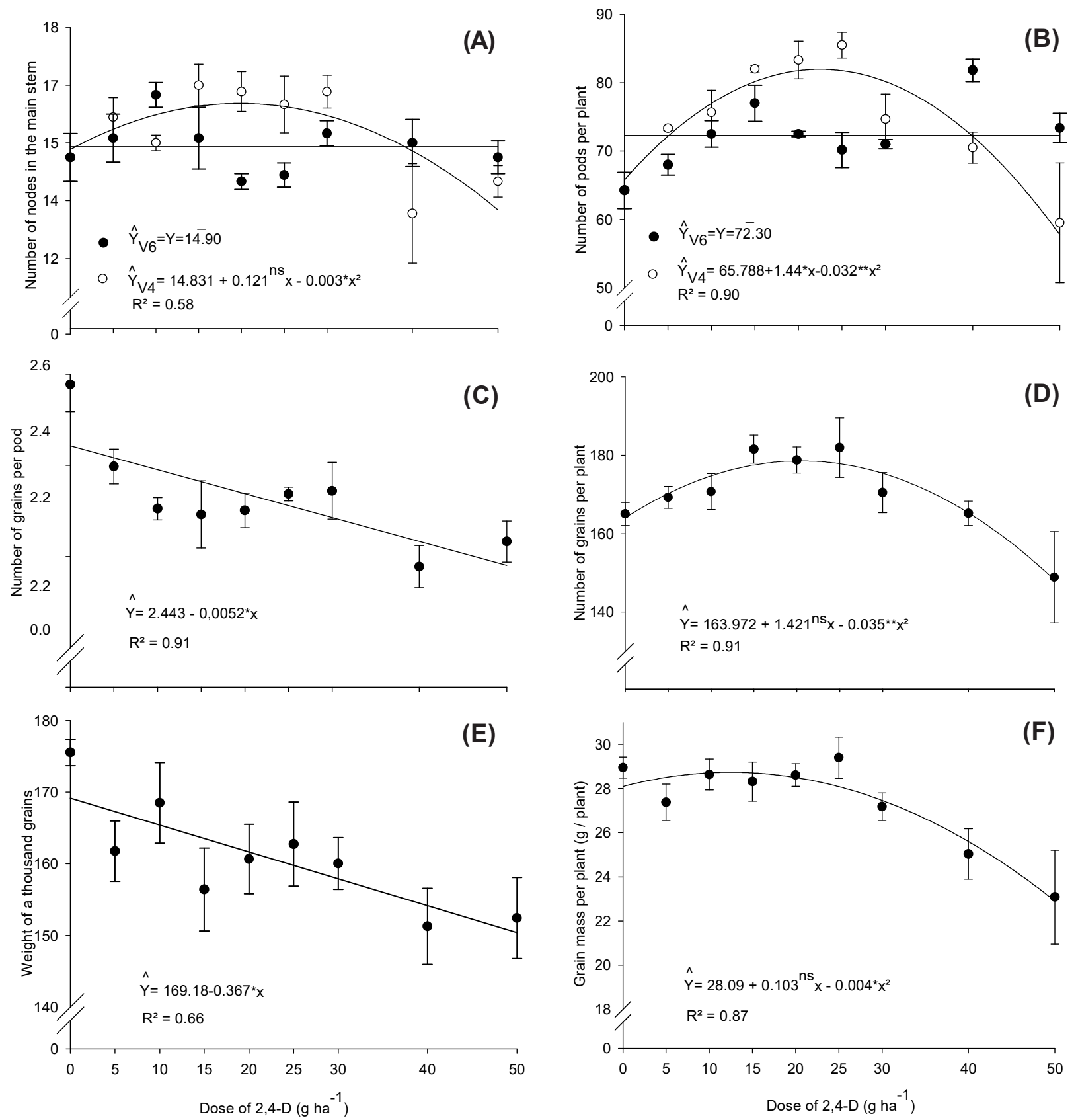

*, **: Significant at $5 \%$ and $1 \%$ of probability, respectively, by the t-test. ns: not significant. The dispersion refers to the mean standard deviation of the average $(n=4$ or $n=8)$.

Figure 3 - Effect of sub-doses of 2,4-D applied at two stages of development (V4 and V6) of soybean plants on number of nodes in the main stem, number of pods per plant, number of grains per pod, number of grains per plant, weight of a thousand grains, and grain mass per plant.

Furthermore, WTG, similarly to GPP, was linearly reduced with the increase of the dose of 2,4-D, regardless of the application stages (Table 2, Figure 3E). At the dose of $20 \mathrm{~g} \mathrm{ha}^{-1}$ (which, according to the results stated above, stimulated NPP during V4 and GPL during V4 and V6), the WTG reduction was only $4.4 \%$, while at the highest tested dose (50 $\left.\mathrm{g} \mathrm{ha}^{-1}\right)$, it was $11,1 \%$ when compared to the control treatment. Despite the (discrete) inhibitory effect of 2,4-D on this variable (WTG), and also on GPP, the increase of NPP and, consequently, of GPL stimulated by low doses of 2,4-D was responsible for ensuring a significant effect of the dose of 2,4-D on plant productivity as expressed by GMP (Table 2, Figure 3F). This can be demonstrated by the relatively high correlation coefficient between GPL and GMP $(r=0.72, p<0.01)$. Therefore, it was verified that 
GMP increased with the increase of the dose of 2,4-D, with the maximum value of $28.75 \mathrm{~g}$ per plant reached at the dose of $12.88 \mathrm{~g} \mathrm{ha}^{-1}$ (Figure $3 \mathrm{~F}$ ), thus characterizing the hormetic effect of this herbicide.

In the field, doses around 7 to $10 \mathrm{~g} \mathrm{ha}^{-1}$ (slightly lower than the ones found in this study), have been successfully used under certain circumstances. It should be emphasized that GMP is the integrated end result of almost all other physiological components of the crop yield (except for the number of plants per hectare (Board et al., 1992; Navarro Júnior and Costa, 2002; Fageria et al., 2006; Costa, 2013), i.e., it represents the crop yield in this work.

Even if the above result (for GMP) occurred regardless of the application stage, soybean cultivation was more sensitive to the toxicity and the consequent inhibition of growth resulting from 2,4-D application during V4, since WTG and GMP were lower when the herbicide was applied during V4, when compared to V6 (Tables 2 and 3). Therefore, 2,4-D doses that are higher than those inducing hormetic effects seem to more strongly compromise soybean growth and productivity when applied during V4 than during V6. In practical terms, these results suggest that the threshold between the doses of 2,4-D that promote hormetic effects and those that significantly toxify the culture is very narrow during V4, requiring rigor in the technology in order to apply the correct doses. This may also explain the failures reported in the field (productivity losses owing to 2,4-D toxicity).

Table 3 - Number of nodes in the main stem (NNMS), number of pods per plant (NPP), number of grains per pod (GPP) number of grains per plant (GPL), weight of a thousand grains (WTG), and grain mass per plant (GMP) depending on the stages of development in which the herbicide was applied to the plant, regardless of their doses

\begin{tabular}{|l|c|c|c|c|c|c|}
\hline \multirow{2}{*}{ Stage } & \multicolumn{7}{|c|}{ Overall averages of the analyzed variables $^{(1)}$} \\
\cline { 2 - 8 } & NNMS & NPP & GPP & GPL & WTG $(\mathrm{g})$ & GMP $(\mathrm{g})$ \\
\hline V4 & 15.29 & 74.00 & 2.31 & 171.48 & 152.60 & 26.20 \\
\hline V6 & 14.90 & 72.30 & 2.30 & 168.90 & $169.47^{*}$ & $28.60^{*}$ \\
\hline Overall average & 15.10 & 73.15 & 2.31 & 170.19 & 161.04 & 27.40 \\
\hline
\end{tabular}

(1) The presence of * indicates a significant difference between the stages by the F-test at $5 \%$ of probability.

There are few studies in the literature with results of hormesis caused by 2,4-D or some other herbicide with a hormetic effect on soybeans. Tavares et al. (2017) applied sub-doses of 2,4-D on pequi seedlings and showed hormetic effects based on the leaf area, specific leaf area, and leaf area ratio with doses of $3.3 \mathrm{~g} \mathrm{ha}^{-1}, 1.65 \mathrm{~g} \mathrm{ha}^{-1}$, and $3.35 \mathrm{~g} \mathrm{ha}^{-1}$, respectively. In a study carried out by Silva (2014), the hormetic effect was shown on soybean crops, but with the application of sub-doses of glyphosate. In this case, the application of $3.6 \mathrm{~g} \mathrm{ha}^{-1}$ of glyphosate followed by a fresh application of $3.2 \mathrm{~g} \mathrm{ha}^{-1}$ after 14 days induced the maximum growth of the plant shoot, probably in response to the increase in the production of amino acids. Also, Silva (2014) verified that, for total dry mass, a dose of $7.2 \mathrm{~g} \mathrm{ha}^{-1}$ of glyphosate, applied 14 days after an application of an initial dose of $18.2 \mathrm{~g} \mathrm{ha}^{-1}$, provided a more evident hormetic effect.

When taken together, the results of this study allow us to conclude that the use of a small dose of 2,4-D (around $13 \mathrm{~g} \mathrm{ha}^{-1}$ ) during V4 or V6 can lead to a significant increase in crop productivity, confirming the hypothesis of the work. However, more trials with different soybean cultivars are required under different growing conditions, especially in the field, with different 2,4-D formulations or other auxinic herbicides, in order to evaluate if the response found here (hormesis) is in fact a general response of soybean to auxinic herbicides. Nevertheless, the careful use of 2,4-D for this purpose is recommended, since excessive doses may compromise crop productivity, especially if applied during V4.

\section{ACKNOWLEDGMENTS}

This work was supported by the Fundação de Amparo à Pesquisa do Estado de Minas Gerais - FAPEMIG (grant FORTIS-TCT-10254/2014). 


\section{REFERENCES}

Agrostat. Estatística de Comércio Exterior do Agronegócio Brasileiro. Estatística. [acessado em: 06 Set. 2018]. Disponível em: http://indicadores.agricultura.gov.br/agrostat/index.htm.

Allender WJ. Effect of trifluoperazine and verapamil on herbicide stimulated growth of cotton. J Plant Nutr. 1997;20(1):69-80.

Anunciato VM. Efeitos do glyphosate no crescimento e reprodução de biótipos de Digitaria insularis resistente ou suscetível a este herbicida. [dissertação]. Botucatu: Universidade Estadual Paulista "Júlia de Mesquita Filho"; 2018.

Board JE, Kamal M, Harville BG. Temporal importance of greater light interception to increased yield in narrow-row soybean. Agron J. 1992;84:575-9.

Board N, Maricherla D. Explanations for decreased harvest index with increased yield in soybean. Crop Sci. 2008;48:1995-2002.

Bridges DC. Glyphosate-type herbicidas. In: Herbicide action course. West Lafayette: 2003. p.501-13.

Calabrese EJ, Baldwin LA. Defining hormesis. Human Exp Toxicol. 2002;21(2):91-7.

Cobb AH, Reade JPH. Herbicides and plant physiology. $2^{\text {nd }}$. ed. Oxford: Wiley-Blackwell; 2010. 286p.

Companhia Nacional de Abastecimento - Conab. Acompanhamento da safra brasileira: grãos: safra 2017/18 - décimo primeiro levantamento - agosto de 2018. [acessado em: 06 Set. 2018]. Disponível em: https://www.conab.gov.br/info-agro/safras/graos.

Costa ED. Arranjo de plantas, características agronômicas e produtividade de soja. [dissertação]. Botucatu: Universidade Estadual Paulista "Júlia de Mesquita Filho"; 2013.

Duke SO, Cedergreen N, Velini ED, Belz RG. Hormesis: is it an important factor in herbicide use and allelopathy? Outlooks Pest Manag. 2006;17(1):29-33.

Fageria NK, Baligar VC, Clark RB. Physiology of crop production. New York: Food Products Press; 2006.

Fehr WR, Caviness CE. Stages of soybean development. Ames: Iowa State University of Science and Technology; 1977. (Special Report, 80).

Gitti DC, Arf O, Peron IBG, Portugal JR, Corsini DCDC, Rodrigues RAF. Glyphosate como regulador de crescimento em arroz de terras altas. Pesq Agropec Trop. 2011;41(4):500-7.

Goodwin TW, Mercer EI. The plant cell wall. In: Introduction to plant biochemistry. New York: Pergamon Press; 1983. p.55-91.

Heiffig LS, Câmara GMS, Marques LA, Pedroso DB, Piedade SMS. Plasticidade da cultura da soja (Glycine max (1.) merrill) em diferentes arranjos espaciais. Braz J Agric. 2010;84(3):204-19.

Luckey TD. Radiation hormesis. Boca Raton: CRC Press; 1991.

Luckey TD. Radiation hormesis: the good, the bad, and the ugly. Dose-Response. 2006;4:169-90.

Monquero PA. Plantas transgênicas resistentes aos herbicidas: situação e perspectivas. Bragantia. 2005;64(4):517-31.

Müller L. Taxonomia e morfologia. In: Miyasaka S, Medina JC, editores. A soja no Brasil. Campinas: Instituto de Tecnologia de Alimentos; 1981. p.65-104.

Navarro Junior HM, Costa JA. Contribuição relativa dos componentes do rendimento para produção de grãos em soja. Pesq Agropec Bras. 2002;37(3):269-74.

Neter J, Wasserman V, Kutner MH. Applied linear statistical models: regression, analysis of variance and experimental designs. Homewood: Richard A. Irwin; 1990. 842p.

Rayle DL, Cleland RE. The acid growth theory of auxin-induced cell elongation is alive and well. Plant Physiol. 1992;99:1271-4.

Ribeiro AC. Calagem. In: Comissão de Fertilidade do Solo do Estado de Minas Gerais. Recomendações para uso de corretivos e fertilizantes em Minas Gerais: 5a aproximação. Viçosa, MG: CFSEMG; 1999. p.43-60. 
Robinson AP, Davis VM, Simpson DM, Johnson WG. Response of soybean yield components to 2,4-D. Weed Sci. 2013;61(1):68-76.

Silva AA, Ferreira FA, Ferreira LR. Herbicidas: classificação e mecanismo de ação. In: Silva AA, Silva JF, editores. Tópicos em manejo de plantas daninhas. Viçosa, MG: Universidade Federal de Viçosa; 2007. p.83-148.

Silva FML. Hormesis de herbicidas em soja. [tese]. Botucatu: Universidade Estadual Paulista "Júlia de Mesquita Filho"; 2014.

Silva JC, Gerlach GAX, Rodrigues RAF, Arf O. Influência de doses reduzidas e épocas de aplicação sobre o efeito hormético de glyphosate em feijoeiro. Rev Fac Agr. 2016;115(2):191-9.

Slife FW. The effect of 2,4-D and several other herbicides on weeds and soybeans when applied as post-emergence sprays. Weed Sci. 1956;4(1):61-8.

Taiz L, Zeiger E, Möller IM, Murphy A. Fisiologia e desenvolvimento vegetal. 6a .ed. Porto Alegre: Artmed; 2017. 858p.

Tavares CJ, Pereira LS, Araújo, ACF, Martins DAM, Jakelaitis A. Crescimento inicial de plantas de pequi após aplicação de 2, 4D. Pesq Flor Bras. 2017;37(89):81-7.

United States Department of Agriculture - USDA. Foreign Agricultural Service. Oilseeds: World Markets and Trade. [accessed at: 15 May 2018]. Available on: https://downloads.usda.library.cornell.edu/usda-esmis/files/tx31qh68h/8w32r601z/1g05fb91f/oilseedtrade-05-10-2018.pdf.

Van Roekel RJ, Purcell LC, Salmerón M. Physiological and management factors contributing to soybean potential yield. Field Crops Res. 2015;182:86-97.

Velini ED, Alves E, Godoy MC, Meschede DK, Souza RT, Duke SO. Glyphosate applied at low doses can stimulate plant growth. Pest Manag Sci. 2008;64(4):489-96.

Wax LM, Knuth LA, Slife FW. Response of soybeans to 2,4-D, dicamba, and picloram. Weed Sci. 1969;17(3):388-393. 